Hakemli

\title{
30.09.2015 TARIHHLİ HGK KARARI VE SONRASI EVLİ KADININ SOYADINA İLISSKKIN BİR DEĞERLENDİRME
}

Current Developments on the Surname of Married Woman After 2015

\author{
Burcu Bahar ÇATALOĞLU* \\ Seldağ GÜNEŞ PESCHKE***
}

\section{ÖZET}

Türk hukukunda kadının soyadına ilişkin düzenlemeler, 4721 sayılı Türk Medeni Kanunu'nda ve 2525 sayılı Soyadı Kanunu'nda yer almaktadır.

TMK m. 187'ye göre, evlilik birliği içinde erkek, evlilikten önceki soyadını kullanmaya devam ederken; kadına bu hak tanınmamıştır. Bu durum, Anayasa'da yer alan eşitlik ilkesine aykırı görülerek birçok yargı kararına konu olmuştur.

Konuyla ilgili ilk dava, 1995 yılında Ayten Ünal Tekeli tarafindan açılmıştır. O dönemde yürürlükte olan 743 sayılı TMK m. 153 uyarınca, yerel mahkeme ve Yargıtay, Ünal Tekeli'nin evlilik öncesi soyadını tek başına kullanma talebini reddetmişlerdir. Anılan tarihte Anayasa Mahkemesi'ne bireysel başvuru hakkı olmadığı için, AİHM önüne gelen dava Ünal Tekeli'nin lehine sonuçlanmıştır.

Bunu takip eden yıllarda kadının evlilik soyadına ilişkin gerek iç hukukta gerek AİHM'de pek çok dava açılmıştır. AİHM'e giden davalarda, kadının evlendikten sonra, sadece evlilik öncesi soyadını kullanma yönündeki talepleri, mahkeme tarafından haklı bulunmuştur. Ancak, bu kararlara rağmen, uygulamada bir değişiklik olmamış, kadın evlilik sonrası, TMK m.

Makalenin Geliș Tarihi: 14.08.2020, Makalenin Kabul Tarihi: 19.08.2020

Ar. Gör., Ankara Yıldırım Beyazıt Üniversitesi Medeni Usul ve İcra İflas Hukuku Anabilim Dal1, b.bahar@hotmail.com, ORCID: 0000-0002-6855-6975

** Prof. Dr., Ankara Yıldırım Beyazıt Üniversitesi Karşılaştırmalı Hukuk Anabilim Dalı Başkan1, seldag.peschke@gmx.net, ORCID: 0000-0003-3679-6525 
187 gereği, kocasının soyadını kullanmak zorunda kalmıştır. Bununla birlikte, kadın, eğer isterse, evlilik öncesi soyadını kocasının soyadından önce kullanabilmektedir.

Oysaki birçok ülkede, kadına evlilikten önceki soyadını tek başına kullanma hakkı verilmiştir. Kadının evlilik soyadı konusunda çeşitli ülkelerde farklı hukuki düzenlemeler bulunmaktadır.

Anayasa Mahkemesi'nde de bireysel başvuru yolunun kabulünün ardından evli kadının soyadı konusunda farklı dönemlerde, çeşitli davalar görülmüştür. Bu davalarda Anayasa Mahkemesi, AİHM'in daha önce vermiş olduğu kararlar doğrultusunda değerlendirme yapmış ve evli kadının evlilik birliği içerisinde evlilik öncesi soyadını tek başına kullanabilmesi gerektiğine karar vermiştir.

Nihayet, 2014/2-889 E., 2015/2011 K. sayılı ve 30 Eylül 2015 tarihli Yargıtay Hukuk Genel Kurulu kararıyla, evli kadının evlilik birliği içinde yalnızca kendi soyadını kullanmasının bir insan hakkı olduğuna; bu hakkın kadın ve erkek arasında eşit şekilde uygulanması gerektiğine karar verilmiştir. Ancak TMK m. 187'de halen bir değişiklik yapılmadığı için, bu hakkın kullanımı ancak kadın evlendikten sonra, soyadına ilişkin dava açması halinde mümkün olabilmektedir. $\mathrm{Bu}$ makalede, eski düzenlemelere değinilerek 2014/2-889 E., 2015/2011 K. Sayılı HGK kararından günümüze kadar geçen sürenin bir değerlendirmesi yapılacaktır.

Anahtar Kelimeler: isim, kadının soyadı, TMK m. 187, evlenme, evlilik birliği.

\section{ABSTRACT}

The legal regulations on the surname of women are regulated in Turkish Civil Code No. 4721 and Code of Surname No. 2525.

According to Turkish Civil Code Article 187; in marriage, men continue to use their family surnames as they were, where women have to use the surname of their husbands. This legal situation makes a contradiction according to principle of equality in Turkish Constitution Article 10.

Unal Tekeli v. Turkey, was the first case taken to European Court of Human Rights on the surname of married women. After individual application to Constitutional Court was put into force in Turkey, several cases on this matter have taken action. In these cases, Constitutional Court have decided in favor of women according to the regulations in ECHR and CEDAW. Finally, Turkish Supreme Court has changed its previous decisions on 2015, and 
adjudged in favor of women that using their surname before marriage is a human right and both of the spouses should enjoy this right equally. Even though, Article 187 of TCC still hasn't been changed, it is considered that women can use their surname before marriage, if they sue after getting married.

In many countries married women can continue to use their own surnames before marriage. In this article, surname of married women will be examined within examples of different countries according to Turkish Court decisions, especially after the decision of General Assembly of Civil Chambers of Supreme Court in 2015.

Keywords: surname, gender equality, Turkish Civil Code, personality rights, union of marriage.

\section{Giriş}

Türk Dil Kurumu Güncel Türkçe Sözlük’te ad “Bir kimseyi, bir şeyi anlatmaya, tanımlamaya, açıklamaya, bildirmeye yarayan söz, isim, nam." olarak ifade edilmiștir'. Öztan'a göre ad, "Bir kimseyi hemcinslerinden ayırt eden, onu belirten bir kelimedir." ${ }^{2}$. Dural ve Öğüz ise adı "Kişileri, diğger kişilerden ayıran ve toplumsal ilişkilerde onu belirleyen bir tanttım, bir işaret" olarak tanımlamaktadır ${ }^{3}$. Buna göre ad, bir kişinin, toplumda bulunan diğer kişilerden ${ }^{4}$, ayırt edilerek belirtilmesini sağlar, kişiyi dış dünyada temsil eder ${ }^{5}$.

Ön ad ve soyadı, birlikte ismi oluşturur ${ }^{6}$. Aynı aileye mensup bireyleri birbirinden ön ad ayırırken, ${ }^{7}$ soyadı bir kişinin toplumda mevcut ailelerden hangisine dahil olduğunun tespitini sağlar ${ }^{8}$. Kişinin birden fazla ön adı

https://sozluk.gov.tr/ (Erişim Tarihi: 02.04.2020).

Öztan, Bilge, Medeni Hukukun Temel Kavramlarl, Ankara 2016, s. 295.

Dural, Mustafa / Öğüz, Tufan, Kişiler Hukuku, İstanbul 2016, s. 165.

4 Güneş Peschke, Seldağ, Roma Hukukundan Günümüze Kişilik Haklarının Korunması (Iniuria), Ankara 2014, s. 80

5 Özel, Sibel, Uluslararası Alanda Medya ve Internette Kișilik Hakkının Korunması, Ankara 2004, s. 31

6 Erdoğan, İhsan: "Şahsiyeti İncitici Soyadı Meselesi"; Selçuk Üniversitesi Hukuk Fakültesi Dergisi Prof. Dr. Süleyman Arslan'a Armağan, Konya 1998, Cilt: 6 Sayı: 1-2, s. 705-712, s. 705.

7 Akıntürk, Turgut, Medeni Hukuk Başlangıç Hükümleri Şahsın Hukuku - Aile Hukuku, Ankara 1968, s. 111.

8 Abik, Yıldız, Kadının Soyadı ve Buna Bağll Olarak Çocuğun Soyadı, Ankara 2005, s. 31; Özsunay, Ergun, Gerçek Kişilerin Hukuki Durumu, İstanbul 1970, s. 104; Özdemir, Hayrünnisa. "Türk ve İsviçre Hukukunda Ad Üzerindeki Hak ve Korunması"; $A \ddot{U H F D}$ 
olabilir 9039 sayılı Nüfus Hizmetleri Kanunu ile Bazı Kanunlarda Değişiklik Yapılmasına Dair Kanunun ${ }^{10}$ 5. maddesi ile 5490 sayılı Nüfus Hizmetleri Kanununun ${ }^{11} 15$. maddesinde yapılan değişiklik sonrası, maddenin 5. fikrasında "Çocuğa konulan ad, üç adl geçmemek üzere ve kısaltma yapılmadan yazılır." hükmü yer almaktadır. Buna göre, bir çocuğa verilebilecek ön ad sayısı üçle sınırlandırılmış olup, çocuğa daha fazla ön ad verilemeyecektir.

Kural olarak soyadı sadece bir tane olabilir. Ancak bu kuralın tek istisnası, evli kadının soyadında karşımıza çıkmaktadır. 1934 yılında 2525 sayılı Soyadı Kanunuyla ${ }^{12}$ ülkemizde soyadı kullanımı zorunlu hale getirilmiştir. Böylece, soyadı kişinin kimliğinin ayrılmaz bir parçası haline gelmiştir. $^{13}$

Kişiyi dış dünyaya karşı temsil eden isim, bu açıdan kişilik haklarından biridir $^{14}$ ve TMK m. 23, 24, 25 yanında, TMK m. 26 ve $27^{\prime}$ 'de de ayrıca ve özel olarak koruma altına almıştır"15. Yargıtay da 2017 tarihli kararında, "Ad ve soyadı kişiliğin ayrılmaz bir unsurudur." diyerek adın, kişilik haklarından biri olduğunu vurgulamıştır ${ }^{16}$.

Ankara 2008, Cilt: 57 Say1: 3, s. 561-598, s. 564; Y1lmaz, Merve, "Evli Kadının Soyadı", Türkiye Adalet Akademisi Dergisi Yargıtay Onursal Başkanı A. Nazım Kaynak'a Armağan, Ankara 2012, Cilt: 1 Say1: 10 Y1l: 3, s. 129-151, s. 130.

9 Ataay, Aytekin, "Medeni Hukukda Ad ile İlgili Temel Bilgiler"; İstanbul Üniversitesi Hukuk Fakültesi Mecmuası, İstanbul 1960, Cilt: 26 Say1 1-4, s. 185-208, s. 193-195.

107039 sayılı Nüfus Hizmetleri Kanunu ile Bazı Kanunlarda Değişiklik Yapılmasına Dair Kanun, 03.11.2017 tarihli ve 30229 sayılı Resmi Gazetede yayımlanmıştır.

115490 sayılı Nüfus Hizmetleri Kanunu, 29.04.2006 tarihli ve 326153 sayılı Resmi Gazetede yayımlanmıştır.

122525 sayılı Soyadı Kanunu, 02.07.1934 tarihli ve 2741 sayılı Resmi Gazetede yayımlanmıştır.

13 Güneş Peschke, Seldağ: "The Surname of Turkish Women: A Question of Identity?"; Journalism and Mass Communication, Libertyville USA 2015, Volume: 5 No: 12, s. 658665 , s. 659.

14 Abik, s. 138; Moroğlu, Nazan, Kadının Soyadı, İstanbul 1999, s. 23; Akipek, Jale / Akıntürk, Turgut / Ateş Karaman, Derya, Türk Medeni Hukuku I. Cilt Başlangıç Hükümleri Kişiler Hukuku, İstanbul 2012, s. 432; Oğuzman, M. Kemal / Seliçi, Özer / Oktay-Özdemir, Saibe: Kişiler Hukuku, İstanbul 2009, s. 106; Dural / Öğüz, s. 165; Erdoğan, s. 706; Ataay, s. 202 Anayasa Mahkemesi de 10.03.2011 tarihli ve 2009/85 E., 2011/49 K. sayıl1 kararında "Bir kimsenin kimliğinin belirlenmesinde en önemli unsur olan soyad, vazgeçilmez, devredilmez, kişiye sıkı surette bağlı bir kişilik hakkıdır." diyerek soyadı üzerindeki hakkın kişilik haklarına dahil olduğunu belirtmiştir (Karar, 21.10.2011 tarihli ve 28091 sayılı Resmi Gazetede yayımlanmıştır.).

15 Güneş Peschke, Inıuria, s. 81.

16 Yargitay 8. Hukuk Dairesi'nin 2017/6122 E., 2017/14423 K. sayll ve 02.11.2017 tarihli karar1. Karar metnine https://karararama.yargitay.gov.tr/YargitayBilgiBankasiIstemciWeb/ adresinden erişilmiştir (Erişim Tarihi: 22.06.2020). 
Hukukumuzda soyadı farklı yollarla kazanılmaktadır. Soyadı doğum ile kazanılır, ancak bununla birlikte, evlat edinme, idari karar ve mahkeme kararı yoluyla da soyadı kazanılabilmektedir. Hukukumuzda sadece kadına özgü bir yol olarak, evlenme yoluyla da soyadi alınabilmektedir ${ }^{17}$.

\section{Evli Kadının Soyadına İlişkin Hukuki Düzenlemeler}

\section{A. Genel Olarak}

1926 tarihli ve 743 say1l Türk Kanunu Medenisi'nin 153. maddesinde, soyadı konusunda "Karı, kocasının aile ismini taşır." şeklinde bir düzenleme vard1. Bu kanun maddesi emredici nitelikte olduğu için, eşlerin aralarında anlaşmaları durumunda dahi değiştirilemiyordu ${ }^{18}$.

743 sayılı TMK m. 153,'te 1997 yılında bir değişiklik yapıldı ${ }^{19}$. Bu değişikliğin gerekçesinde kadının evlilikten önce iş veya meslek hayatında kendi soyadıyla tanınmış olması yahut başka gerekçelerle evlilikten önceki soyadını kaybetmek istememesi halinde, kocasının soyadı önünde kendi evlilik öncesi soyadını da kullanabilmesinin bir ihtiyaç olarak ortaya çıktığı ifade edildi. Mevcut düzenlemenin soyadı konusunda kadını mutlak anlamda kocaya tabi kılması karşısında; kadınlara karşı ayrımcılığın önüne geçilmesi ve kadının kendi soyadını kullanması açısından değişikliğin gerekli olduğu belirtilmiştir ${ }^{20}$. Bu değişiklik sonucunda, evli kadının isteği halinde kocasının soyadı önünde, evlenmeden önceki soyadını da taşıyabileceği yönünde bir düzenleme yapıldı. Ancak kadının, evlenince kocasının soyadını almasına ilişkin düzenleme maddenin yeni halinde de devam etti ${ }^{21}$.

2002 yılında yürürlüğe giren 4721 sayılı Türk Medeni Kanununda $(\mathrm{TMK})^{22}$, kadının soyadı hakkındaki hüküm korunmuş, TMK m. 187; "Kadın, evlenmekle kocasının soyadını alır; ancak evlendirme memuruna veya daha

17 Abik, s. 56; Moroğlu, s. 39; Y1lmaz, s. 138.

18 Moroğlu, s. 87.

194248 say1lı Türk Kanunu Medenisinin 153 üncü Maddesinin Birinci Fikrasının Değiştirilmesine Dair Kanun, 22.05 .1997 tarihli ve 22996 sayılı Resmi Gazetede yayımlanmıştır.

${ }^{20}$ Kanun değişikliğinin gerekçesini de içeren Türk Kanunu Medenisinin Birinci Fıkrasının Değiştirilmesine Dair Kanun Tasarısı ve Adalet Komisyonu Raporu'na https://www.tbmm.gov.tr/tutanaklar/TUTANAK/TBMM/d20/c026/tbmm20026093ss0285. pdf adresinden erişilmiş̧ir (Erişim Tarihi: 27.07.2020).

21 Moroğlu, s. 89; Y1lmaz, s. 139.

224721 sayılı Türk Medeni Kanunu, 08.12.2001 tarihli ve 24607 sayılı Resmi Gazetede yayımlanmıştır. 
sonra nüfus idaresine yapacă̆ yazılı başvuruyla kocasının soyadı önünde önceki soyadını da kullanabilir. Daha önce iki soyadı kullanan kadın, bu haktan sadece bir soyad için yararlanabilir." şeklinde aynen muhafaza edilmiştir. Bu madde düzenlemesi uyarınca, evlenme halinde, kadın ya tek başına kocasının soyadını alacak veya evlenmeden önceki kendi aile soyadının yanında kocasının soyadını kullanacaktır. Kısacası, evlenen kadın için eşinin soyadını almamaya yönelik bir seçme hakkı bulunmamaktadır.

Almanya, İtalya, Fransa gibi birçok Avrupa ülkelerinin yanı sıra, İran, Suriye gibi ülkelerde de kadın isterse, evlendikten sonra kocasının soyadını almadan, evlilik öncesi soyadını kullanmaya devam edebilmektedir.

Evlenme yoluyla soyadının kazanılması, birçok ülkede hem kadın hem de erkek için mümkündür. Ayrıca, bazı ülkelerde evlilikle birlikte, erkek de kadının soyadını almayı tercih etmekte ve kadının soyadı aile soyadı olarak kullanılmaktadır. Örneğin Almanya'da eşler evlendikten sonra kendi soyadlarını birbirlerine verebilmekte veya kendileri için aile soyadı olarak, kendi soyadları dışında başka bir soyadını da alabilmektedirler.

Medeni Kanunumuzun mehazı olan İsviçre Medeni Kanunu'nda (Schweizerisches Zivilgesetzbuch - ZGB) evlilik soyadı hakkındaki m. 160'ta yer alan düzenlemeler tarihi süreç içinde incelendiğinde, başlangıçta evlilikle birlikte, kadının kocasının soyadını alacağı düzenlendiği görülmektedir. 1988 y1lında yürürlüğe giren bir değişiklikle, haklı bir nedenin varlığı halinde kadının soyadının da aile adı olarak seçilebilmesinin önü açılmıştır. Ayrıca bu düzenleme çerçevesinde, aile adının erkeğin soyadı olarak belirlenmesi halinde kadın, kocasının soyadı önünde kendi soyadını da kullanabilmekteydi ${ }^{23}$.

İsviçre Medeni Kanunu'nda 2013 yılında yürürlüğe giren son değişikliklerle birlikte, m. 160'ın mevcut düzenlemesi uyarınca evlilikte eşler evlilik öncesi soyadlarını devam ettirebilmektedirler. Bununla birlikte, eşler evlilik birliği içinde, eşlerden birinin soyadını aile adı olarak da kullanabilirler.

Almanya'da, Alman Medeni Kanunu'nun (Bürgerliches Gesetzbuch BGB) 1355. maddesine göre evlilik birliği içerisinde eşler, ortak bir soyadı belirleyebilir. Bu ortak soyadı eşlerden herhangi birinin soyadı olabilir. Ortak

23 MacClintock, Heather: "Sexism, Surnames and Social Progress: The Conflict of Individual Autonomy and Government Preferences in Laws Regarding Name Changes at Marriage"; Temple International \& Comparative Law Journal, Philadelphia USA 2010, Volume: 24 Issue: 1, s. 277-312, s. 283. 
soyadı belirlenmemişse, eşler evlilik öncesi soyadlarını evlilikte de kullanmaya devam ederler. Kendi soyadı ortak aile adı olarak belirlenmeyen eş, yapacağı bir bildirimle doğumla kazandığı soyadını yahut bildirim anındaki soyadını, yeni aile adının önüne veya arkasına ekleyebilir.

Almanya ve İsviçre'deki düzenlemeler oldukça benzer olmasına rağmen, tüm Kıta Avrupası ülkelerinde durum aynı değildir. Örneğin Fransa'da, evliliğin eşlerin soyadları üzerinde bir etkisi bulunmamaktadır. Fransa'da isim değiştirilmesi, ancak Fransız Medeni Kanununun (Code Civil) 61. ve devamı maddeleri gereğince meşru bir nedenin varlığı halinde ve mahkeme kararı ile yapılabilir. Nelerin "meşru neden" teşkil ettiğine dair Fransız Medeni Kanunu'nda bir belirleme yapılmamış olup, kavramın içeriği Fransız Danıştayı'nın (Conseil d'Etat) içtihatlarıyla belirlenmiştir. Buna göre, kişinin adının gülünç veya utanç verici olması yahut yabancı dildeki bir soyadını bırakıp Fransızca bir soyadı almak istemesi meşru neden kabul edilirken; duygusal veya ticari nedenler bu kapsamın dışında tutulmuştur ${ }^{24}$.

Günümüzde yüzölçümü bakımından dünyanın en büyük ülkelerinden biri olan Kanada, on eyalet hükümeti ve üç kuzey bölgesinin oluşturduğu federal bir yapıdadır ${ }^{25}$. Bu eyaletlerin çoğunda, aile adı olarak her iki eşten birinin soyadı kullanılmaktadır. On eyaletin en büyügü olan ve resmi dili Fransızca olan Quebec ${ }^{26}$ ise, Anglosakson Hukuk sistemine dahil olan ülkenin geri kalanından farklı olarak, Fransız Hukukundan etkilenmiştir. Quebec, evlilik soyadı konusunda da diğer eyaletlerden farklı bir yaklaşım benimsemiş ve evlilikte her iki eşin de mevcut soyadlarını kullanmaya devam etmelerini, erkek veya kadın olması önemli olmaksızın eşlerin evlilik birliğinde soyadlarını değiştirmemelerini kanunen düzenlemiştir ${ }^{27}$.

İç işlerinde bağımsız olan elli federe eyaletten oluşan Amerika Birleşik Devletleri'nde $^{28} \quad$ kadınlar, evlenmeleri halinde mevcut soyadlarını kullanmaya devam etme veya kocanın soyadını kullanma hususunda seçim hakkına sahiptir ${ }^{29}$.

24 Guibert-Lantoine, Catherine de: "Changing Surnames in France"; içinde Valetas, MarieFrance: "The Surname of Married Women in the Europian Union"; Population\&Sociétés, Paris 2001, No: 367, s. 1-4, s. 4.

25 Özensel, Ertan: "Çokkültürlülük Uygulaması Olarak Kanada Çokkültürlülüğ̈̈’; Akademik Incelemeler Dergisi, Sakarya 2012, Cilt: 7 Say1 1, s. 55-70, s. 61, 62.

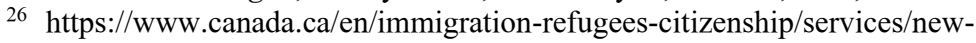
immigrants/prepare-life-canada/provinces-territories/quebec.html (Erişim Tarihi: 12.04.2020).

27 Quebec Medeni Kanunu (Civil Code of Quebec) SQ 1991, Cha pter 64, Art. 393.


10.04.2020).

29 MacClintock, s. 291-292. 
Asya ülkelerinden Çin Halk Cumhuriyeti, Evlilik Kanunu'nda evlilikte karı ve kocanın eşit haklara sahip olduğunu hükme bağlamıştır. Yine bu kanuna göre, her iki eşin de evlilikte kendi soyadlarını kullanabilmeleri mümkün kılınmıştır.

Japonya'da eşler evlilik anındaki anlaşmalarına göre kadının veya erkeğin soyadını alabilirler ${ }^{30}$. Japonya'da evlilikler Aile Sicili Kanununa ${ }^{31}$ göre idareye bildirilmekte ve kaydedilmektedir. Eğer evlilik soyadı üzerinde bir anlaşma sağlanamazsa, bildirim formundaki tüm zorunlu alanların doldurulmaması nedeniyle bildirim reddedilecek ve evlilik tanınmayacaktır ${ }^{32}$. Aile Sicili Kanunu, 6. maddesinde aileyi aynı soyadını taşıyan karı koca ve onların çocuklarından oluşan bir birim olarak tanımlamaktadır.

Oldukça geleneksel ve ataerkil bir aile yapısına sahip olan İran'da, egemen kabul edilen ailenin en yaşlı erkeğine itaat edilmesi beklenir ${ }^{33}$. Buna rağmen, kadın evlilikte kendi soyadını devam ettirir, ancak kocasından izin belgesi getirerek onun soyadını alması mümkündür. Bu şekilde kocasının soyadını alan kadının eski soyadına dönmek istemesi halinde başvurusu üzerine soyadı eski haline döndürülür ${ }^{34}$.

Ülkemizde evlilik birliği içinde kadının evlilik öncesi soyadını kullanmaya devam etmesi mümkün değilken, erkeğin de doğrudan kadının soyadını alabilme hakkı bulunmamaktadır ${ }^{35}$. Evlilik birliği kurulduğu anda, kadın kocasının soyadını almak zorundadır. Koca ise, kendi soyadını kullanmaya devam etmektedir.

Anayasanın 10. maddesinde düzenleme altına alınan eşitlik ilkesi uyarınca, "Herkes, dil, ırk, renk, cinsiyet, siyasi düşünce, felsefi inanç, din, mezhep ve benzeri sebeplerle ayırım gözetilmeksizin kanun önünde eşittir. Kadınlar ve erkekler eşit haklara sahiptir. Devlet, bu eşitliğin yaşama geçmesini sağlamakla yükümlüdür.".

\footnotetext{
30 Japonya Medeni Kanunu (Kanun numarası 89, 1896), m. 750.

31 Family Register Act, kanun numaras1 224, 1947.

32 Kamiya, Masako: "Women in Japan"; University of British Columbia Law Review, Vancouver 1986, Volume: 20 Issue: 2, s. 447-470, s. 447-470, s. 455.

33 Nassehi-Behnam, Vida: "Change and The Iranian Family"; Current Anthropology, Volume 26, No: 5 (December 1985), s. 557-562, s. 557.

34 http://iranianembassy.nl/en/consular.php?content=27013 (Erişim Tarihi: 09.04.2020).

35 Abik, s. 59; Moroğlu, s. 40.
} 
İnsan Hakları Evrensel Beyannamesi, ${ }^{36}$ Avrupa İnsan Hakları Sözleşmesi ${ }^{37}$ gibi uluslararası anlaşmalarda da eşitlik ilkesi esas alınmış, tüm insanların eşit olduğu ve hiçbir nedenle ayrımcılık yapılamayacağ 1 vurgulanmıştır. Birleşmiş Milletler Kadınlara Karşı Her Türlü Ayrımcılığın Önlenmesi Sözleşmesinde (CEDAW $)^{38}$ de kadın erkek eşitliği vurgulanmış, kadın ve erkeklerin "soyad, meslek ve iş seçme hakları da dahil karı ve koca olarak aynı kişisel haklara sahip olma"ları gerektiği (m. 16/1-g) düzenlenmiştir. Türkiye bu maddeye başlangıçta iç hukukla bağdaşmadığ 1 gerekçesiyle koymuş olduğu çekinceyi, 1999 yılında kaldırmıştır ${ }^{39}$.

Anayasamızın 90. maddesinin 5. fikrası uyarınca, yukarıda belirtilen ve Türkiye'nin usulüne uygun bir şekilde taraf olduğu uluslararası anlaşmalar da ulusal mevzuatımıza dahildir. Bu doğrultuda, evlilik birliği içinde kadın ve erkeğe eşit haklar tanınması gerekmektedir. Evli kadının soyadı konusunda kadın ve erkek için farklı uygulamaların bulunması, eşitlik ilkesine aykırıdır. Ulusal mevzuatımızda, evlilik birliğiyle birlikte, soyadına ilişkin mevcut düzenlemeler çerçevesinde, kocaya e tanınan haklar, kadına aynı şekilde tanınmamıştır.

\section{B. Boşanma Halinde Kadının Soyadı}

Kadının evlilik esnasında zorunlu olarak değiştirilen soyadının, boşanma halinde kullanımı eski eşin iznine bağlı kılınmıştır. Nitekim konuyu düzenleyen TMK m. 173 hükmüne göre; boşanan kadın, evlenmeden önceki soyadını tekrar alır. Kadının, boşandığı kocasının soyadını kullanmaya devam etmek istemesi halinde ise, bunda bir menfaati bulunduğunu ve bunun eski kocasına bir zarar vermeyeceğini hâkim önünde ispatlaması gerekmektedir. Aksi halde hâkim, kadının, boşandığı kocasının soyadını kullanmasına izin vermeyebilir. $\mathrm{Bu}$ izni verip vermeme konusunda hâkime takdir yetkisi

36 Bakanlar Kurulunun 06.04.1949 tarihli ve 9119 sayılı İnsan Hakları Evrensel Beyannamesinin Remi Gazetede yayımlanmasina dair kararı, 27.05.1949 tarihli ve 7217 sayılı Resmi Gazetede yayımlanmıştır.

376366 sayılı İnsan Haklarını ve Ana Hürriyetleri Koruma Sözleşmesi ve Buna Ek Protokolün Tasdiki Hakkında Kanun, 19.03.1954 tarihli ve 8662 sayılı Resmi Gazetede yayımlanmıştır.

38 Birleşmiş Milletler Genel Kurulu'nun 18.12.1979 tarihli ve 34/180 sayılı kararıla kabul edilerek imzaya, onaya ve katılmaya açılan sözleşme, 03.09.1981 tarihinde yürürlüğe girmiştir. Türkiye'nin bu sözleşmeye katılması, 25.06.1985 tarihli ve 18792 sayılı Resmi Gazetede yayımlanan 3232 sayılı Kanunla uygun bulunmuş ve Bakanlar Kurulunun 24.07.1985 tarihli ve 85/9722 sayılı kararıyla onaylanmıştır. Bakanlar Kurulunun onay kararı ve Kadınlara Karşı Her Türlü Ayrımcılığın Önlenmesi Sözleşmesi metni, 14.10.1985 tarihli ve 18898 sayılı Resmi Gazetede yayımlanmıştır.

39 Ünal Özkorkut, Nevin, "Kadının Vazgeçilebilir Kişilik Hakkı: Soyadı - Kadının Soyadı Üzerindeki Hakkının Türkiye'deki Tarihsel Gelişimi", I. Türk Hukuk Tarihi Kongresi Bildirileri, İstanbul 2014, s. 23-30, s. 26. 
tanınmıştır. TMK m. 173'te yer alan düzenlemeye göre, boşanma sonrasında eski eşinin izni ile evlilik soyadını kullanan kadın, koşulların değişmesi halinde, eski kocasının soyadını iade etmek zorunda kalabilmektedir. Eski eşin bu talebi için herhangi bir zaman sınırı da öngörülmemiştir.

Anılan düzenlemeler, kocanın kişilik hakkını korurken, kadın açısından eşitlik ilkesine aykırı bir durum yaratmaktadır. TMK m. 173 düzenlemesinde bu husus göz ardı edilmiş, kadının kişilik hakkına nazaran erkeğin kişilik hakk1 daha üstün tutulmuştur ${ }^{40}$.

Adalet Bakanlığg Adli Sicil ve İstatistik Genel Müdürlüğü 2019 verilerine göre, boşanan kadının kocasının soyadını kullanmasına izin verilmesine ilişkin 2016 yılında 421, 2017 yılında 434, 2018 y1lında 465 dava açılmıştır. 2019 yılında bu sayı, önceki yıla göre \%13,8 oranında artış göstererek 529'a çıkmıştır ${ }^{41}$.

Boşanma sonrasında eski kocasının soyadını kullanmasına hakim tarafından izin verilen kadınlara karşı, bu iznin kaldırılmasına ilişkin olarak eski eş tarafından 2016 yılında 263, 2017 yılında 245, 2018 yılında 171, 2019 y1lında ise 156 dava açılmıştır ${ }^{42}$.

Boşanma sonrasında evlenmeden önceki soyadını tekrar alan kadınların karşılaştı̆̆ 1 bir diğer problem ise, velayeti kendisine bırakılan ortak çocuğuyla farklı soyadları taşımakta olmasıdır. Nitekim TMK m. 321 uyarınca anne ve babası evli olan çocuk, ailenin soyadını taşıyacaktır. TMK m. 187 uyarınca evlenen kadın kocasının soyadını alacağından, aile soyadı kocanın soyadı olmaktadır. Dolayısıyla anne ve babası evli olan çocuk da, babasının soyadını almaktadir ${ }^{43}$.

40 Moroğlu, s. 103,104.

41 Adli İstatistikler 2019, T.C. Adalet Bakanlığı Adli Sicil ve İstatistik Genel Müdürlüğü, Ankara, $\quad$ s. 162 http://www.adlisicil.adalet.gov.tr/Resimler/SayfaDokuman/1062020170359HizmeteOzel2019-bask\%C4\%B1-\%C4\%B0SA.pdf (Erişim Tarihi: 20.05.2020).

42 Boşanma ve Boşanma ile İliş̧ili Davalar, 6284 sayılı Ailenin Korunması ve Kadına Karşı Şiddetin Önlenmesine dair Kanun ile İlgili İstatistikler 2012-2019, T.C. Adalet Bakanlığ 1 Adli Sicil ve İstatistik Genel Müdürlüğü, Ankara.

43 Abik, s. 55; Dural / Öğüz, s. 160; Oğuzman / Seliçi / Oktay Özdemir, s. 96; Akipek / Akıntürk / Ateş Karaman, s. 425; Ayan, Serkan: "Anayasa Mahkemesi Kararları ve Çocuklar ile Kadının Soyadına İlişkin Değişiklik Tasarısı Taslağı Işı̆̆ında Soyadının İlk Kez Edinilmesi, Kendiliğinden Değişmesi ve Değiştirilmesi"; Gazi Üniversitesi Hukuk Fakültesi Dergisi, Ankara 2012, Cilt: XVI, Say1: 4, s. 19-90, s. 23; Özdemir, s. 571; Y1lmaz, s. 133. Anayasa Mahkemesi de 07.10.2009 tarihli ve 27369 sayılı Resmi Gazetede yayımlanan, 02.07.2009 tarihli ve 2005/114 E., 2009/105 K. Sayılı kararında "... evlilik içinde doğan 
Soyadı Kanunu m. 4/2'nin ilk cümlesi olan "Evliliğin feshi veya boşanma hallerinde çocuk anasına tevdi edilmiş olsa bile babasının seçtiği veya seçeceği adı alır." cümlesi, Anayasa Mahkemesi tarafından, Anayasanın 10. ve 41. maddelerine aykırı olduğu gerekçesiyle iptal edilmiştir ${ }^{44}$.

$\mathrm{Bu}$ iptal kararının ardından, boşanma sonrası ortak çocuğun velayetini almış olan kadınlar, babasının soyadını taşımakta olan çocuğun soyadının değiştirilmesi ve çocuğa annenin soyadının verilmesi talebiyle pek çok dava açmışlardır. Bu davalar ilk derece mahkemelerinde kadın lehine sonuçlanmış olsa da, Yargıtay çeşitli kararlarında, genel bir değerlendirme yaparak, salt boşanmış olmanın ve velayet hakkına sahip olmanın anneye çocuğun soyadını değiştirme konusunda dava hakkı vermeyeceğini belirtmiştir. ${ }^{45}$.

Anayasa Mahkemesi, bireysel başvuru üzerine 25.06.2015 tarihinde karara bağladığ 1 Hayriye Özdemir ${ }^{46}$ davasında, boşanma sonrasında ortak çocuğun velayetine sahip kadının, çocuğa kendi soyadını verebileceğine hükmetmiştir. AYM, bu talebin kabul edilmemesinin aile hayatına saygı hakkına müdahale olduğunu ve bu müdahalenin, Soyadı Kanunu m. 4/2'nin ilk cümlesinin iptali sonrasında kanuni olmadığını, dolayısıyla ihlal teşkil ettiğini hükme bağlamıştır. Böylelikle boşanan kadınların, velayeti kendilerine bırakılmış olan ortak çocuğa kendi soyadlarını verebilmelerinin önü açılmıştır. Aynı konuda Anayasa Mahkemesi önüne bireysel başvuru yoluyla gelen başka uyuşmazlıklarda da aynı yönde karar verilmiştir ${ }^{47}$.

Bununla birlikte, açılan her davada mahkemelerin farklı yönde kararlar verebileceği de göz önünde bulundurulmalıdır. Nitekim yakın zamanda Yargıtay 2. Hukuk Dairesi tarafindan verilen 20.06.2020 tarihli kararda, boşanma sonucunda ortak çocuğun velayeti kendisine bırakılmış olan annenin, sadece velayet hakkına dayanarak çocuğun soyadının

çocuğun ailenin (diğer bir ifadeyle babanın) soyadını taşıyacă̆ı..." ifadesini kullanarak bu hususu vurgulamıştır.

44 Anayasa Mahkemesinin 08.12.2011 tarihli ve 2010/119 E., 2011/165 K. Sayılı kararı, 14.02.2012 tarihli ve 28204 sayılı Resmi Gazetede yayımlanmıştır.

45 Yargitay Hukuk Genel Kurulunun 15.03.2015 tarihli ve 2013/18-1755 E., 2015/1039 K. Sayıl1 karar1; Yargitay 18. Hukuk Dairesinin 18.06.2013 tarihli ve 2013/9343 E., 2013/10704 K. Say1l karar1.

46 Başvuru No: 2013/3434.

47 Gülbu Özgüler Başvurusu, Başvuru No: 2013/7979, Karar Tarihi: 11.11.2015; Nurcan Yolcu Başvurusu, Başvuru No: 2013/9880, Karar Tarihi: 11.11.2015; Ayten Yıldırmaz Başvurusu, Başvuru No: 2014/1826, Karar Tarihi: 20.07.2017; Deniz Altınbaş ve Diğerleri Başvurusu, Başvuru No: 2014/2033, Karar Tarihi: 26.10.2017; S. E. Başvurusu, Başvuru No: 2017/40178, Karar Tarihi: 26.02.2020; E. Ç. Başvurusu, Başvuru No: 2018/6565, Karar Tarihi: 10.06.2020. 
değiştirilmesini isteyemeyeceği hükme bağlanmıştır. Yerel mahkemece çocuğa annenin soyadının verilmesi yönünde verilen karara, babanın itiraz etmesi sonucunda başlayan süreçte Yargitay, bu tip davalarda çocuğun üstün yararının gözetilmesi gerektiğini ifade ederek, çocuğun annenin soyadını almasında üstün yararı olduğu ispatlanamadığı için yerel mahkeme kararının bozulmasına karar vermiştir ${ }^{48}$.

\section{Kadının Soyadına İlişkin 30 Eylül 2015 Tarihli Hukuk Genel Kurulu Kararı ve Sonrasındaki Gelişmeler}

TMK'da yer alan ve yukarıda açıklanan düzenlemeler sonucunda, kadının kimliği hem evlenme hem de boşanma hallerinde değişmekte ve her medeni hal değişiminde kadın farklı bir kimliğe bürünmektedir. Erkek açısından söz konusu olmayan bu durum, kadın açısından eşitlik ilkesine


olmuştur.

1998 yılında, 743 sayılı Türk Medeni Kanunu döneminde, evlilik soyadını düzenleyen m. 153, Anayasa'ya aykırı olduğu gerekçesiyle somut norm denetimi yoluyla iptal istemiyle Anayasa Mahkemesi önüne getirilmiştir ${ }^{50}$.

Mahkeme yapmış olduğu incelemede; itiraza konu olan "Kadın evlenmekle kocasinın soyadını alır" kuralının sebebi olarak; bazı sosyal gerçeklerin doğurduğu zorunlulukların varlığını ve yasa koyucunun yıllar boyunca yerleşmiş olan bir geleneği kurumsal hale getirmiş olmasını göstermiştir. Anayasa Mahkemesi, aile birliğinin sağlanması amacıyla yasa koyucu tarafından eşlerden birine öncelik tanındığını ve kamu yararı, kamu düzeni ve birtakım zorunluluklar nedeniyle soyadının kocadan diğer eşe geçmesinin tercih edildiğini belirtmiştir.

$48 \mathrm{https} / /$ www.aa.com.tr/tr/turkiye/yargitaydan-cocugun-soyadinin-degistirilmesine-iliskinustun-yarar-kriteri/1922167, https://www.sozcu.com.tr/2020/gundem/yargitaydan-emsalsoyadi-karari-5952597/, https:/www.sabah.com.tr/gundem/2020/07/25/yargitaydan-emsalniteliginde-soyadi-karari?paging=6 (Erişim Tarihi: 26.07.2020).

49 Esen, Emre: "Türk Vatandaşı Erkeğin Yabancı Eşinin Soyadını Alamayacağına İlişkin Bir Yargıtay Kararı Üzerine Düşünceler"; MHB Prof. Dr. Sevin Toluner'e Armağan, İstanbul 2004, Y11: 24 Say1: 1-2 2004, s. 439-449, s. 449; Akbulut, Pakize Ezgi: "Türk ve Alman Hukukunda Evlenme ve Boşanmanın Kişinin Soyadına Etkisi ve Milletlerarası Özel Hukukta Ortaya Çıkan Sorunlar"; İzmir Barosu Dergisi, İzmir 2011, Y11: 76 Sayı: 3, s. 6078 , s. 67.

50 Anayasa Mahkemesinin 743 Sayılı Türk Kanunu Medenisinin 153. Maddesinin İptali İsteminin Reddine İlişkin 29.09.1998 Tarihli ve 1997/61 E., 1998/59 K. Say1lı Kararı, 15.11.2002 tarihli ve 24937 sayılı Resmi Gazetede yayımlanmıştır. 
Mahkeme, haklı bir nedenin varlığı halinde, kişilerin farklı kurallara tabi olmalarının eşitlik ilkesini ihlal etmediğini, konum ve durumlarından kaynaklanan özellikler sebebiyle bazı kişi ve topluluklar hakkında farklı düzenlemelerin gerekli olabileceğini ifade etmiştir. $\mathrm{Bu}$ bağlamda, yasa koyucu tarafindan, aile soyadı olarak kocanın soyadına öncelik verilmesinin, sayılan haklı nedenler çerçevesinde eşitlik ilkesine aykırılık oluşturmadığına karar vermiştir.

Bireysel olarak sadece kendi soyadını kullanabilmek için dava yoluna başvuran ilk evli kadın Ayten Ünal Tekeli'dir. Türkiye'de iç hukuk yollarını tüketen ancak talebine ulaşamayan Ünal Tekeli, dosyayı Avrupa İnsan Hakları Mahkemesi önüne taşımıştır. Bu başvuru Aralık 1995'te yapılmış olmakla birlikte, karar tarihi Kasım 2004'tür. ${ }^{51}$

Başvuruyu inceleyen Avrupa İnsan Hakları Mahkemesi, kadınlar evlilik birliği içinde hukuken kendi soyadlarını tek başına kullanamazlarken erkeklerin böyle bir durumla karşılaşmamalarının, benzer konumdaki kişiler arasında cinsiyete dayalı "farklı muamele" oluşturduğunu tespit etmiştir. Bu davada cinsiyetler arası farklı muameleyi haklı kılacak ikna edici gerekçeler bulunmadığını ifade eden AİHM, başvurucu lehine karar vermiştir. Mahkeme, bu kararın ardından Türkiye'ye karşı yapılan aynı konudaki başvurular hakkında da, bu davayı emsal göstererek, evli kadınların sadece kendi soyadını kullanabileceği yönünde karar vermiştir.

Bireysel başvuru yolunun hukukumuza girmesinin ardından, Anayasa Mahkemesi önüne bu yolla evlilik birliği içinde kadının kendi soyadını tek başına kullanabilmesine ilişkin davalar da getirilmiştir ${ }^{52}$. Bu davalarla ilgili olarak Anayasa Mahkemesi, kadının evlilik soyadıyla ilgili uyuşmazlıklarda uluslararası sözleşme hükümlerinin uygulanması gerektiğine karar vermiştir. Bu bağlamda, Avrupa İnsan Hakları Sözleşmesi ve BM Kadınlara Karşı Her Türlü Ayrımcılığın Önlenmesi Sözleşmesi'nin ilgili hükümleri ile AİHM'in bu konudaki kararlarına atıf yapan Anayasa Mahkemesi, kadının evlilikte yalnızca kendi soyadını kullanabilmesi gerektiğini ifade etmiştir.

51 Ayten Ünal Tekeli'nin 20.12.1995 tarihli ve 29865/96 numaralı başvurusu üzerine Avrupa İnsan Hakları Mahkemesinin vermiş olduğu 16.11.2004 tarihli karar metnine http://hudoc.echr.coe.int/eng\#\{"fulltext":["ünal tekeli"],"documentcollectionid2": ["GRANDCHAMBER","CHAMBER"],"itemid":["001-67482"]\} adresinden erişilmiştir (Erişim tarihi: 12.04.2020).

52 Sevim Akat Eşki Başvurusu, Başvuru No: 2013/2187, Karar Tarihi: 19.12.2013; Gülsim Genç Başvurusu, Başvuru No: 2013/4439, Karar Tarihi 19.12.2013; Neşe Aslanbay Akbıyık Başvurusu, Başvuru No: 2014/5836, Karar Tarihi: 16.04.2015. 
Yakın zamana kadar evli kadının evlilikte sadece kendi soyadını kullanmasına ilişkin talepleri reddeden Yargıtay da, 30 Eylül 2015 tarihli ve 2014/2-889 E., 2015/2011 K. Sayılı Hukuk Genel Kurulu karariyla ${ }^{53}$ bu görüşünü değiştirmiştir. Bu kararda Yargıtay Hukuk Genel Kurulu, aile birliğini ortak bir aile ismiyle yansıtma amacının cinsiyete dayalı farklı muamele için yeterli bir gerekçe oluşturmayacağını, söz konusu farklı muamelenin AİHS'ne açıkça aykırı olduğunu belirtmiştir. Genel Kurul, evli kadının sadece kendi soyadını kullanmasının bir insan hakkı olduğuna; bu hakkın cinsiyete dayalı bir ayrım olmaksızın kadın ve erkek arasında eşit şekilde uygulanması gerektiğine karar vermiştir.

Anlatılan bu olumlu kararlara rağmen, hukukumuzda evli kadının soyadını düzenleyen TMK m. 187'de halen bir değişiklik yapılmamıştır. Bu nedenle evli kadınlar, evlilik birliği içinde sadece kendi soyadlarını kullanma hakkını ancak dava yoluyla elde edebilmektedir. Bu haliyle evli kadının soyadı konusu, ülkemizde bir sorun teşkil etmeye devam etmektedir.

$\mathrm{Bu}$ sorunların somut bir örneğini, Anayasa Mahkemesi'nin Ayşe Sena Sezgin Arslan tarafindan yapılan bireysel başvuru sonucunda verdiği kararda da görmekteyiz ${ }^{54}$. Başvurucu, evlenme akdi gerçekleştirilmeden önce idareye verdiği dilekçeyle, evlenme akdinden sonra soyadı hanesine, eşinin soyadı kullanılmadan, sadece bekarlık soyadının yazılmasını talep etmiştir. İdare, başvurucuya verdiği cevapta TMK m. 187 hükmünden ve bu maddenin iptali için Anayasa Mahkemesi'nde açılmış olan davanın reddine ilişkin 2009/85 Esas, 2011/49 Karar sayılı ve 10.03.2011 tarihli kararından bahisle talebi reddetmiştir.

Bunun üzerine, diğer başvuru yollarının başarı şansı bulunmadığını, masraflı ve zaman kaybına yol açacak yollar olduğunu düşünen başvurucu, doğrudan doğruya Anayasa Mahkemesine bireysel başvuruda bulunmuştur. Anayasa Mahkemesi, başvuru yollarının etkisiz olacağı konusunda somut veriler olmadığını, etkili bir giderim yolu olarak hukuk davası açma imkanının bulunduğunu belirtmiştir. Anayasa Mahkemesi'ne bireysel başvuruda bulunabilme şartlarından olan tüm başvuru yollarının tüketilmiş olması koşulunun yerine getirilmediğini tespit eden Mahkeme, başvuruyu bu sebeple kabul edilemez bularak reddetmiştir.

Karara konu olay incelendiğinde, AİHM ve Anayasa Mahkemesi bireysel başvuru kararlarının varlığına rağmen, idari makamlar tarafından, TMK m.

53 Yargitay Hukuk Genel Kurulunun 30.09.2015 Tarihli ve 2014/2-889 E., 2015/2011 K. Sayılı Karar1.

54 Ayşe Sena Sezgin Arslan Başvurusu, Başvuru No: 2014/13367, Karar Tarihi: 15.04.2015. 
187 hükmünün hala yürürlükte olmasını gerekçe göstererek, kadının evlilik birliği içinde sadece kendi soyadını kullanmasına ilişkin talepleri reddettiği somut olarak görülmektedir. Anayasa Mahkemesi'nin etkili giderim yolu olarak hukuk mahkemesi önünde dava açılması imkanını işaret etmiş olması da özellikle dikkat çekicidir.

Kadınların evlilik birliği içerisinde sadece kendi soyadlarını kullanma taleplerine ilişkin hukuk mücadelesi, ülkemizde 1995 yılında Ayten Ünal Tekeli'nin Karşıyaka Asliye Hukuk Mahkemesi'ne yaptı̆̆ 1 başvuruyla başlamış; AİHM, Anayasa Mahkemesi ve Yargıtay'ın verdiği çeşitli kararlar neticesinde günümüzdeki haline ulaşmıştır. Kadınların evlilik soyadı konusunda cinsiyete dayalı ayrımcılığa karşı eşitlik ve hak talepleri halen devam etmektedir.

30 Eylül 2015 tarihli Yargıtay Hukuk Genel Kurulu kararından günümüze kadar geçen 5 yıl içerisinde, konuyla ilgili herhangi bir yüksek yargı kararı bulunmamaktadır. Bu çerçevede HGK, kadının evlilik birliği içinde, tek başına evlenmeden önceki soyadını kullanmasına ilişkin kararıyla son noktayı koymuştur. HGK kararı sonrası, ilk derece mahkemeleri, kadınların evlilik birliği içerisinde sadece evlilik öncesi soyadlarını kullanmaya ilişkin taleplerini olumlu karşılamaktadır.

Bu konuda açılan davalara ilişkin bir istatistiki veri olmadığ 1 için, ilk derece mahkemelerinde kadının evlilik öncesi soyadının kullanmasına ilişkin açılan davaları analiz etme imkânı bulunmamaktadır.

Sonuç olarak, TMK m. 187'nin halen yürürlükte olması karşısında idari makamlar, kadınların evlilikte sadece evlilik öncesi soyadlarını kullanma isteklerini hala reddetmektedirler. Anayasa Mahkemesi de bu durum karşısında etkili başvuru yolu olarak dava yolunu göstermektedir ${ }^{55}$. Kadınların, kişilik haklarının bir parçası olan adlarını eşitlik ilkesi çerçevesinde koruyabilmek için dava yoluna zorlanması, usul ekonomisine aykırı olmasının yanı sıra; bu konudaki ayrımcılı̆̆ın halen devam ettiğinin bir göstergesidir. Bu soruna kesin olarak son verebilmek için, evlilik birliğinde soyadını düzenleyen TMK m. 187 ve boşanma halinde kadının soyadını düzenleyen TMK m. 173 hükümlerinde kanunkoyucu tarafindan bir an önce değişiklik yapılması ve konunun yasal zemine kavuşturulması önem arz etmektedir.

\footnotetext{
55 Ayşe Sena Sezgin Arslan Başvurusu, Başvuru No: 2014/13367, Karar Tarihi: 15.04.2015.
} 


\section{Sonuç}

Türkiye'de, henüz Soyadı Kanunu yürürlüğe girmemişken ve dolayısıyla herkes için bir soyadı kullanma zorunluluğu bulunmamaktayken, İsviçre Medeni Kanunu temel alınarak hazırlanan 753 sayılı Türk Kanunu Medenisi'nin 153. maddesiyle, evli kadınların kocasının soyadını almasını zorunlu kılan düzenleme hukukumuza girmiştir.

İsviçre, tarihi süreç içerisinde bu zorunluluğu önce yumuşatmış, sonra tamamen kaldırmıştır. Kimi ülkelerde baştan beri hiç konulmamış olan bu zorunluluk, diğer bazı ülkelerde ise sonradan kaldırılmıştır. Türkiye'de ise, maddenin ilk halinde değişiklik yapılmış ve evli kadının kocasının soyadı önünde bekarlık soyadını da kullanabileceği kabul edilmiş olmakla birlikte; evlilikte soyadının değiştirilmesi mecburiyeti, sadece kadın açısından devam etmektedir.

4721 sayılı Türk Medeni Kanunu m. 187'de yer alan, kadını evlenmekle bu konudaki rızasına bakılmaksızın soyadını değiştirmeye zorlayan bu düzenlemenin, kadınların temel haklarını ihlal ettiği Avrupa İnsan Hakları Mahkemesi'nin (AİHM) çeşitli kararlarıyla tespit edilmiştir. Buna rağmen, Anayasa Mahkemesi bu kanun maddesinin iptali için açılan davayı kabul etmemiştir. Yargıtay da kadınların evlilik birliği içinde tek başına evlenmeden önceki soyadını kullanmaya ilişkin taleplerini reddetmeye devam etmiştir.

Bireysel başvuru yolunun hukuk sistemimize girmesinin ardından Anayasa Mahkemesi, Türkiye'nin taraf olduğu Avrupa İnsan Hakları Sözleşmesi (AİHS) ve Kadınlara Karşı Her Türlü Ayrımcılığın Önlenmesi Sözleşmesi (CEDAW) hükümlerini esas alarak, evli kadının sadece kendi soyadını kullanabilmesi yönünde kararlar vermiştir. Anayasa Mahkemesi'nin bu kararları, daha önce aynı konuda AİHM tarafından verilmiş olan kararlarla uyum içindedir.

$\mathrm{Bu}$ gelişmeler sonucunda, Yargitay Hukuk Genel Kurulu 30.09.2015 tarihinde vermiş olduğu kararla önceki içtihadını değiştirmiştir. Türkiye'nin taraf olduğu uluslararası sözleşmeleri, mevcut AİHM ve Anayasa Mahkemesi kararlarını ve öğretideki eleştirileri dikkate alarak verdiği yeni kararıyla; Yargıtay da doğumla kazanmış olduğu soyadına evlilik nedeniyle rızası gözetilmeden müdahale edilmesinin kadının kişilik haklarının ihlali olduğunu ve sadece kadın için öngörülen düzenlemenin bu haliyle eşitlik ilkesine aykırı olduğunu kabul etmiş bulunmaktadır.

Kanımızca evlilikte temel ilke olarak eşlerin mevcut soyadlarını devam ettirmesi benimsenmelidir. Eşlerden birinin soyadının ortak aile adı olarak 
seçebilmesine olanak tanınmalıdır. Bununla bağlantılı olarak, evlilikte soyadını değiştirerek artık bu soyadıyla anılmak isteyen kişinin soyadına, boşanma sırasında da müdahale edilmemesi gerekmektedir.

Gerek doktrinde gerekse kamuoyunda oldukça olumlu karşılanan mahkeme kararları, ne yazık ki kadının evlilik soyadı konusunda yaşadıkları olumsuzlukları giderme konusunda yeterli olmamıştır. TMK m. 187'nin hala yürürlükte olması karşısında, idari makamlar evlenen kadınların bekarlık soyadlarını tek başına kullanmaya ilişkin taleplerini reddetmeye devam etmektelerdir. Kadınların evlilik birliği içinde sadece kendi soyadlarını kullanmaya dair taleplerini karşılayabilmelerinin tek yolu dava açmalarıdır. Anayasa Mahkemesi de bu yola işaret emiştir. Ayrıca, her ne kadar Anayasa Mahkemesi ve Yargitay son yıllarda bu konuda kadınlar lehine karar vermekteyse de, kadının evlilik soyadını düzenleyen TMK m. 187 hükmünde değişiklik yapılması usul ekonomisi açısından da bir gerekliliktir.

\section{Kaynakça}

\section{Kitaplar ve Makaleler}

Abik, Yıldız, Kadının Soyadı ve Buna Bağlı Olarak Çocuğun Soyadı, Ankara 2005.

Akbulut, Pakize Ezgi: "Türk ve Alman Hukukunda Evlenme ve Boşanmanın Kişinin Soyadına Etkisi ve Milletlerarası Özel Hukukta Ortaya Çıkan Sorunlar"; İzmir Barosu Dergisi, İzmir 2011, Yı1: 76 Sayı: 3, s. 60-78.

Akıntürk, Turgut, Medeni Hukuk Başlangıç Hükümleri Şahsın Hukuku - Aile Hukuku, Ankara 1968.

Akipek, Jale / Akıntürk, Turgut / Ateş Karaman, Derya, Türk Medeni Hukuku I. Cilt Başlangıç Hükümleri Kişiler Hukuku, İstanbul 2012.

Ataay, Aytekin, "Medeni Hukukda Ad ile İlgili Temel Bilgiler"; İstanbul Üniversitesi Hukuk Fakültesi Mecmuası, İstanbul 1960, Cilt: 26 Say1 1-4, s. 185-208.

Ayan, Serkan: "Anayasa Mahkemesi Kararları ve Çocuklar ile Kadının Soyadına İlişkin Değişiklik Tasarısı Taslağı Işığında Soyadının İlk Kez Edinilmesi, Kendiliğinden Değişmesi ve Değiştirilmesi"; Gazi Üniversitesi Hukuk Fakültesi Dergisi, Ankara 2012, Cilt: XVI, Sayı: 4, s. 19-90.

Boşanma ve Boşanma ile İlişkili Davalar, 6284 sayılı Ailenin Korunması ve Kadına Karşı Şiddetin Önlenmesine dair Kanun ile İlgili İstatistikler 2012-2019, T.C. Adalet Bakanlığı Adli Sicil ve İstatistik Genel Müdürlüğü, Ankara.

Dural, Mustafa / Öğüz, Tufan, Kişiler Hukuku, İstanbul 2016.

Erdoğan, İhsan: "Şahsiyeti İncitici Soyadı Meselesi"; Selçuk Üniversitesi Hukuk Fakültesi Dergisi Prof. Dr. Süleyman Arslan'a Armağan, Konya 1998, Cilt: 6 Sayı: 1-2, s. 705-712. 
Esen, Emre: "Türk Vatandaşı Erkeğin Yabancı Eşinin Soyadını Alamayacağına İlişkin Bir Yargıtay Kararı Üzerine Düşünceler"; MHB Prof. Dr. Sevin Toluner'e Armağan, İstanbul 2004, Y1l: 24 Say1: 1-2 2004, s. 439-449.

Guibert-Lantoine, Catherine de: "Changing Surnames in France"; içinde Valetas, Marie-France: "The Surname of Married Women in the Europian Union"; Population\&Sociétés, Paris 2001, No: 367, s. 1-4.

Güneş Peschke, Seldağ, Roma Hukukundan Günümüze Kişilik Haklarının Korunması (Iniuria), Ankara 2014.

Güneş Peschke, Seldağ: “The Surname of Turkish Women: A Question of Identity?”; Journalism and Mass Communication, Libertyville USA 2015, Volume: 5 No: 12, s. 658-665.

Kamiya, Masako: "Women in Japan"; University of British Columbia Law Review, Vancouver 1986, Volume: 20 Issue: 2, s. 447-470, s. 447-470.

MacClintock, Heather: "Sexism, Surnames and Social Progress: The Conflict of Individual Autonomy and Government Preferences in Laws Regarding Name Changes at Marriage"; Temple International \& Comparative Law Journal, Philadelphia USA 2010, Volume: 24 Issue: 1, s. 277-312.

Moroğlu, Nazan, Kadının Soyadı, İstanbul 1999.

Nassehi-Behnam, Vida: "Change and The Iranian Family"; Current Anthropology, Volume 26, No: 5 (December 1985), s. 557-562.

Oğuzman, M. Kemal / Seliçi, Özer / Oktay-Özdemir, Saibe: Kişiler Hukuku, İstanbul 2009.

Özdemir, Hayrünnisa. "Türk ve İsviçre Hukukunda Ad Üzerindeki Hak ve Korunması"; AÜHFD, Ankara 2008, Cilt: 57 Sayı: 3, s. 561-598.

Özel, Sibel, Uluslararası Alanda Medya ve İnternette Kişilik Hakkının Korunması, Ankara 2004.

Özensel, Ertan: “Çokkültürlülük Uygulaması Olarak Kanada Çokkültürlülüğü”; Akademik İncelemeler Dergisi, Sakarya 2012, Cilt: 7 Say1 1, s. 55-70.

Özsunay, Ergun, Gerçek Kişilerin Hukuki Durumu, İstanbul 1970.

Öztan, Bilge, Medeni Hukukun Temel Kavramları, Ankara 2016.

Ünal Özkorkut, Nevin, "Kadının Vazgeçilebilir Kişilik Hakkı: Soyadı - Kadının Soyadı Üzerindeki Hakkının Türkiye'deki Tarihsel Gelişimi", I. Türk Hukuk Tarihi Kongresi Bildirileri, İstanbul 2014, s. 23-30.

Yılmaz, Merve, "Evli Kadının Soyadı", Türkiye Adalet Akademisi Dergisi Yargıtay Onursal Başkanı A. Nazım Kaynak'a Armağan, Ankara 2012, Cilt: 1 Sayı: 10 Y1l: 3, s. 129-151. 
Ankara Üni. Hukuk Fak. Dergisi, 69 (2) 2020: 399-417 Evli Kadının Soyadına İlişkin Bir Değerlendirme

\section{Elektronik Kaynaklar}

https://sozluk.gov.tr/ (Erişim Tarihi: 02.04.2020).

http://iranianembassy.nl/en/consular.php?content=27013 (Erişim Tarihi: 09.04.2020).

http://www.mfa.gov.tr/amerika-birlesik-devletleri-siyasi-gorunumu.tr.mfa (Erişim Tarihi: 10.04.2020).

https://www.canada.ca/en/immigration-refugees-citizenship/services/newimmigrants/prepare-life-canada/provinces-territories/quebec.html (Erişim Tarihi: 12.04.2020).

http://hudoc.echr.coe.int/eng\#\{"fulltext":["ünal tekeli"],"documentcollectionid2": ["GRANDCHAMBER","CHAMBER"],"itemid":["001-67482"]\} ） (Erişim tarihi: 12.04.2020).

Adli İstatistikler 2019, T.C. Adalet Bakanlığı Adli Sicil ve İstatistik Genel Müdürlüğü, $\quad$ Ankara, http://www.adlisicil.adalet.gov.tr/Resimler/SayfaDokuman/1062020170359Hiz meteOzel-2019-bask\%C4\%B1-\%C4\%B0SA.pdf (Erişim Tarihi: 20.05.2020).

https://karararama.yargitay.gov.tr/YargitayBilgiBankasiIstemciWeb/ (Erişim Tarihi: 22.06.2020).

https://www.aa.com.tr/tr/turkiye/yargitaydan-cocugun-soyadinin-degistirilmesineiliskin-ustun-yarar-kriteri/1922167 (Erişim Tarihi: 26.07.2020).

https://www.sozcu.com.tr/2020/gundem/yargitaydan-emsal-soyadi-karari-5952597/ (Erişim Tarihi: 26.07.2020).

https://www.sabah.com.tr/gundem/2020/07/25/yargitaydan-emsal-niteligindesoyadi-karari?paging=6 (Erişim Tarihi: 26.07.2020).

https://www.tbmm.gov.tr/tutanaklar/TUTANAK/TBMM/d20/c026/tbmm20026093s s0285.pdf (Erişim Tarihi: 27.07.2020). 
B. Bahar ÇATALOĞLU, Seldağ GÜNEŞ PESCHKE Ankara Üni. Hukuk Fak. Dergisi, 69 (2) 2020: 399-417 